\title{
Regulation of microbial populations by coral surface mucus and mucus-associated bacteria
}

\author{
Kim B. Ritchie* \\ Center for Coral Reef Research, Mote Marine Laboratory, 1600 Ken Thompson Parkway, Sarasota, Florida 34236, USA
}

\begin{abstract}
Caribbean populations of the elkhorn coral Acropora palmata have declined due to environmental stress, bleaching, and disease. Potential sources of coral mortality include invasive microbes that become trapped in the surface mucus and thrive under conditions of increased coral stress. In this study, mucus from healthy A. palmata inhibited growth of potentially invasive microbes by up to 10 -fold. Among cultured bacteria from the mucus of A. palmata, $20 \%$ displayed antibiotic activity against one or more tester strains, including the pathogen implicated in white pox disease. A novel mucusmediated selection for coral symbionts revealed a discrete subset of bacteria and selected for isolates that produce antibiotics. This result suggests that coral mucus plays a role in the structuring of beneficial coral-associated microbial communities and implies a microbial contribution to the antibacterial activity described for coral mucus. Interestingly, antibiotic activity was lost when mucus was collected during a summer bleaching event. Isolates from apparently healthy A. palmata tissue during this event lacked antibiotic-producing bacteria and were dominated by members of the genus Vibrio, including species implicated in temperature-dependent bleaching of corals worldwide. This indicates an environmental shift from beneficial bacteria, and variability in the protective qualities of coral mucus, which may lead to an overgrowth of opportunistic microbes when temperatures increase. Finally, coral mucus inhibited antibiotic activity and pigment production in a potentially invasive bacterium, illustrating that coral mucus may inactivate mechanisms used for bacterial niche establishment.
\end{abstract}

KEY WORDS: Surface mucopolysaccharide layer • Coral symbionts · Antibiotics - Coral bleaching . Disease $\cdot$ Pigment production $\cdot$ Chemical defense

Resale or republication not permitted without written consent of the publisher

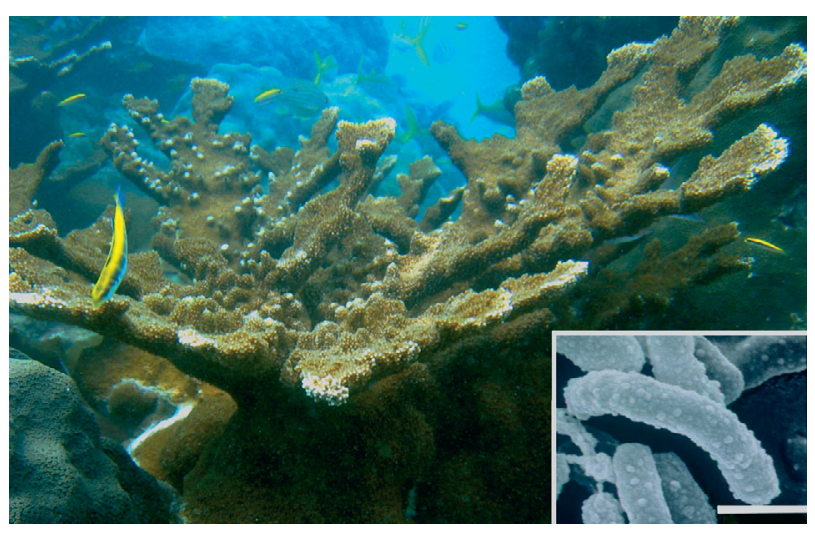

This study found that mucus from healthy Acropora palmata (photo) inhibits the growth of potentially invasive microbes by up to 10 -fold. Conversely, mucus collected during a summer bleaching event lacked antibiotic properties, suggesting that high temperatures reduce the protective function of coral mucus. Inset: Vibrio sp., which at high temperatures replace the community of beneficial bacteria (scale bar $=500 \mathrm{~nm}$ ).

Photos: Kiho Kim (coral), Shawn Polson (inset)

\section{INTRODUCTION}

The decline of corals world-wide has led to a need for a better understanding of disease susceptibility in cnidarians (Harvell et al. 1999). This study focused on protective properties of mucus produced by the elkhorn coral Acropora palmata-one of the first corals proposed for listing as an endangered species in the United States-due to its high susceptibility to environmental stress (e.g. bleaching), disease and physical damage. Coral mucus provides protection from UV, desiccation and increased sediment loading (Brown \& Bythell 2005), but little is known about the protective properties of mucus in disease resistance. Coral mucus is proposed to enhance resistance by a number of mechanisms, including providing a physical barrier between 
the coral and the environment, mucociliary transport of microbes for removal via ingestion by the coral host, sloughing to avoid colonization by invasive microbes, and acting as a medium for secreted allelochemicals with antimicrobial properties (reviewed in Brown \& Bythell 2005). Extracts from soft corals and gorgonian corals have antimicrobial properties (Burkholder \& Burkholder 1958, Kim 1994, Slattery et al. 1995, 1997, Kelman et al. 1998, 2006). Koh (1997) described antimicrobial compounds present in numerous Pacific scleractinian coral species and recent work by Geffen \& Rosenberg (2005) shows that the Red Sea scleractinian coral Pocillopora damicornis exhibits antimicrobial activity. However, the origin of these allelochemicals is unknown.

Corals harbor a diverse array of bacterial associates (reviewed in Brown \& Bythell 2005), some of which are thought to be species-specific (Ritchie \& Smith 1997, Rohwer et al. 2002). To date, very little is known of the metabolic capabilities of these bacteria, their function on the coral surface, and their potential benefit to the coral, zooxanthellae, or both. Bacterial symbionts have been shown to be responsible for the production of secondary metabolites previously attributed to the host organism (Yasumoto et al. 1986, Elyakov et al. 1991). Some marine macroorganisms combat microbial fouling by producing compounds that inhibit bacterial growth or attachment, while others rely on microbial production of defense compounds (Gil-Turnes et al. 1989, Holmstrom et al. 1992, Armstrong et al. 2001). Commensal relationships between bacteria in multispecies biofilms can play a role in determining the spatial distribution of microbial populations within the biofilm (Neilson et al. 2000, Rao et al. 2005). Castillo et al. (2001) determined that $30 \%$ of bacteria isolated from coral species have antibiotic capabilities. The roles played by coral mucus and mucus-associated bacteria in determining the compositions of coral-associated microbial communities are currently unknown.

This study addressed antibiotic activity associated with Acropora palmata mucus and mucus-associated bacteria. Here, antibiotic refers to a substance that selectively kills or inhibits the growth of a microorganism. In addition, an experimental approach was used to investigate the potential of coral mucus as a selection medium for coral symbionts. For the purpose of this study, a symbiont is defined as a bacterium that benefits from properties of the coral mucus while providing a benefit to the coral in return (a mutualistic relationship).

\section{MATERIALS AND METHODS}

Bacterial strains. To isolate culturable bacteria, Acropora palmata mucus samples were diluted in sterile seawater and plated onto glycerol artificial seawater agar (GASWA; Smith \& Hayasaka 1982), followed by incubation at $24^{\circ} \mathrm{C}$. Microorganisms exhibiting a unique colony or cellular morphology (as compared to other colonies on a single plate) were subcultured to purification under the same growth conditions. For ease of performing medium through-put antibiotic assays, 96-well microtiter plate libraries of culturable bacterial isolates were generated. Each library consisted of 96 individually purified coral bacterial isolates stored frozen at $-80^{\circ} \mathrm{C}$ in liquid GASWA medium containing $30 \%$ glycerol. Culturable bacterial libraries were archived for further antibiotic screening and species identification. Strain VBR 7 was isolated from A. palmata mucus in a screen for putative invasive microbes (described below). Other sources of potentially invasive microbes used in this study included canal water from Big Pine canal (Sands, $24^{\circ} 40.31^{\prime} \mathrm{N}$, $\left.81^{\circ} 20.40^{\prime} \mathrm{W}\right)$, dust from Mali, Africa $\left(12^{\circ} 37.22^{\prime} \mathrm{N}\right.$, $7^{\circ} 59.40^{\prime} \mathrm{E}$; provided by V. Garrison, USGS), and water from Looe Key Reef $\left(24^{\circ} 33.78^{\prime}\right.$ N, $\left.81^{\circ} 24.05^{\prime} \mathrm{W}\right)$. Tester strains used for antibiotic assays are described below.

Sampling. Samples were taken from 12 Acropora palmata colonies at various locations at Looe Key Reef, in the Florida Keys $\left(24^{\circ} 32.76^{\prime} \mathrm{N}, 81^{\circ} 24.21^{\prime} \mathrm{W}\right.$ and $24^{\circ} 32.75^{\prime} \mathrm{N}, 81^{\circ} 24.35^{\prime} \mathrm{W}$ ), between January and December of 2005 and were used to generate culturable bacterial libraries for antibiotic production assays. Samples for coral mucus selection experiments were taken from 3 A. palmata colonies in April 2005 (mean water temperature of $24^{\circ} \mathrm{C}$, sustained at 22 to $25^{\circ} \mathrm{C}$ for 2 mo prior to sampling) and $3 \mathrm{~A}$. palmata colonies in September of 2005 (mean water temperature of $30^{\circ} \mathrm{C}$, sustained at 28 to $30^{\circ} \mathrm{C}$ for 2 mo prior to sampling). September samples were taken during a bleaching event in which all $A$. palmata colonies observed were affected by hurricane damage, bleaching or disease. During September sampling, mucus from apparently healthy areas of $A$. palmata colonies was collected. These were areas that appeared healthy, but that were adjacent to entirely bleached areas, or areas with sloughed tissue, in each colony sampled.

To collect samples under field conditions, $30 \mathrm{ml}$ of the surface mucopolysaccharide layer from apparently healthy Acropora palmata were harvested from the skyward-facing, sun-exposed portion of the colony, 5 to $10 \mathrm{~cm}$ from the actively growing edge. Mucus from each colony was consistently collected over an area of $5 \times 5 \mathrm{~cm}$ after gentle agitation with a sterile syringe. Agitation encourages sloughing of the viscous mucus matrix for ease of syringe aspiration, while reducing aspiration of water. Samples were maintained at $24^{\circ} \mathrm{C}$ and processed within $2 \mathrm{~h}$ of collection. Water samples were taken by briefly opening a sterile $15 \mathrm{ml}$ conical tube $1 \mathrm{~m}$ from the coral colony prior to mucus sampling. Water samples were used 
in both mucus challenge experiments and bacterial composition comparisons.

Inhibition of potentially invasive microbes. Sources of potentially invasive microbes were challenged with mucus collected from A. palmata. Potential sources of invasive microbes were chosen based on previous implications to disease causation (Patterson et al. 2002, Garrison et al. 2003). These sources included Florida Keys canal water, African dust, and water column microbes. Mucustreated media were used to test growth inhibition by plating out $400 \mu \mathrm{l}$ of undiluted coral mucus onto GASWA medium and allowing it to dry for $10 \mathrm{~min}$. Mucus treated plates were sterilized via UV irradiation by placing uncovered Petri plates face downward onto a M-26 UVP transilluminator for $10 \mathrm{~min}$ at $302 \mathrm{~nm}$ wavelength. UV irradiation was chosen for sterilization, as mucus is too viscous for filter sterilization and heat/pressure sterilization would greatly alter components, including antibiotic properties, of coral mucus. UV irradiated mucus-treated plates that were left un-inoculated were used to control for complete UV killing in each experiment. To address potential UV alteration of media, inoculates from African dust and canal water were used in control comparisons measuring growth on UV irradiated versus nonirradiated GASWA medium.

Seawater was tested on mucus-treated GASWA medium to address growth inhibition of marine bacteria present in the water column. In order to address coral resistance to potential human-derived water quality contaminants, such as Serratia marscecens or Escherichia coli, mucus-treated Luria Bertani (LB) agar was used when testing Florida Keys canal waterassociated microbes. Dust from Mali, Africa (collected by V. Garrison) was tested on GASWA medium to address inhibition of microbes from dust events with the potential to remain viable in sea water. Both sea water and canal water were concentrated by centrifugation, resuspended in 1/5 volume of supernatant, and inoculated onto each media treatment; $50 \mu \mathrm{g}$ of dust were added to $1 \mathrm{ml}$ of sterile seawater, serially diluted and plated onto GASWA mucus-treated and GASWA control plates.

In addition to potential sources of invasive microbes, both Gram-positive and Gram-negative tester strains were used in mucus inhibition assays to address the range of bacterial inhibition by Acropora palmata mucus. Exponentially growing cultures of each tester strain were serially diluted and assayed as described above. Tester strains included Bacillus subtilis (ATCC $6633 \mathrm{Km}$ resistant), Staphylococcus aureus (MRSA, ATCC 43300), Salmonella typhimurium (ATCC 6994), and the Serratia marsescens white pox isolate, PDL100 (ATCC BAA-632).

Individual experiments were repeated 4 times. Experimental and control plates were incubated at $24^{\circ} \mathrm{C}$ for $48 \mathrm{~h}$. Dilutions containing between 200 and 400 colonies on control media (GASWA + UV treatment) were used in comparison with the corresponding tester plates (GASWA + Mucus + UV treatment). Colony count, mean and SD were recorded for each experiment. To derive measures of fold-inhibition, the experimental mean was divided into the control mean for each experiment.

Antibacterial production assays. Acropora palmata mucus-associated bacteria were used in a primary screen to test for the production of anti-bacterial compounds against a range of tester strains, including: Serratia marcescens PDL100, a pathogen implicated in white pox disease of $A$. palmata (ATCC BAA-632; Patterson et al. 2002), methicillin-resistant Staphylococcus aureus (MRSA; ATCC 43300), methicillin-sensitive S. aureus (MSSA; ATCC 29213), vancomycin-resistant Enterococcus (VRE; Microgenomics), Bacillus subtilis (ATCC $6633 \mathrm{Km}$ resistant), Salmonella typhimurium (ATCC 6994), Enterococcus faecalis (ATCC 29212), Shigella (Microgenomics), Escherichia coli O157 (Microgenomics), and Agrobacterium tumefaciens (Microgenomics). Culturable bacterial libraries, stored in 96-well plate format, were inoculated onto rectangular Petri plates containing GASWA solid medium and grown for $2 \mathrm{~d}$ at $24^{\circ} \mathrm{C}$. Growth of coral bacteria was followed by UV irradiation for 15 to 20 min to inhibit cross contamination from coral-derived bacteria during antibiotic testing. Overnight cultures of tester strains were grown in LB, Tryptic Soy Broth (TSB) or GASWA liquid medium, as appropriate. Strain-specific soft agar medium $(0.8 \%)$ was melted and cooled to $42^{\circ} \mathrm{C}_{;} 8 \mathrm{ml}$ of soft agar was inoculated with individual log-phase tester strains and poured over UV irradiated library plates. Plates were incubated for $2 \mathrm{~d}$ at $30^{\circ} \mathrm{C}$. Growth inhibition resulted in a clear zone of inhibition (non-growth of the overlayed tester strain) around a coral-derived bacterial colony that produced an active antibacterial compound. Zones of inhibition were measured using calipers $(0.02 \mathrm{~mm})$ and scored as distance (in $\mathrm{mm}$ ) from the outside of the clearing zone to the outer edge of the coral-derived bacterial colony tested. Antibiotic spectra of library isolates were used to further dereplicate marine isolates.

Selection for coral bacterial symbionts. To select for antibiotic-producing coral bacteria, a culturebased approach was designed to take advantage of the antibiotic properties associated with Acropora palmata mucus. This method was hypothesized to eliminate bacteria that are inhibited by mucus-associated antibiotic activity (trapped microbes that may become invasive), while selecting for individuals resistant to antibiotic properties of mucus (potentially beneficial coral bacteria, including antibiotic producers). 
This assay was carried out as described above for mucus inhibitory assays. However, instead of challenging mucus-treated plates with sources of potentially invasive microbes, coral mucus dilutions from the same coral colony used to prepare plates were inoculated onto GASWA mucus-treated or GASWA control plates. Colonies were counted and colony forming units (CFUs) per ml estimated for each dilution to represent fold-inhibition. Individual colonies were picked from mucus treated plates to represent potential coral bacterial symbionts (designated as 'residents'). Isolates from the control plates were selected as putative transient bacteria, or bacteria that are potentially invasive under the right conditions ('visitors'). Water column isolates were purified after growth on GASWA medium for comparison to residents and visitors pools.

Mucus inhibition of antibiotic properties in a potentially invasive bacterium. Mucus used in challenge experiments with a potentially invasive microbe (VBR7) was taken from Acropora palmata (April and September 2005, Florida Keys), Pseudopterogorgia americana (April 2005, Florida Keys) and Montastraea faveolata (April 2005, Florida Keys and Flower Garden Banks). From each coral source, $400 \mu \mathrm{l}$ of undiluted coral mucus were plated onto GASWA solid media, allowed to dry for $10 \mathrm{~min}$, and UV irradiated for $10 \mathrm{~min}$ to prevent outgrowth of mucus-associated microbes. Two resulting colony morphologies of VBR7 were dark purple (after growth on GASWA control medium) and white (after growth on each mucus-treated medium). The 2 morphologies of the VBR 7 strain were patched onto replica GASWA plates and assayed for antibiotic activity as described above.

Bacterial identification. For species identification of culturable coral isolates, DNA extraction was performed on each strain via a chemical lysis protocol detailed in Weidner et al. (1996). PCR amplification was carried out on genomic DNA with oligonucleotide forward primer R1n, corresponding to position 22 to 41 of the Escherichia coli 16S rRNA gene, and reverse primer U2 corresponding to complementary position 1085 to 1066 (Weidner et al. 1996). PCR products were electrophoresed on a $1 \%$ agarose gel, and verified using the AlphaImager 3300. A 1100 bp fragment was purified from the PCR reactions using the Qiagen PCR purification kit. PCR products were directly sequenced via BigDye ${ }^{\mathrm{TM}}$ terminator cycling and automated sequencing (Macrogen) using R1n and U2 for forward and reverse strand synthesis (Weidner et al. 1996). Consensus sequences from forward and reverse strands were generated and GenBank BLAST searches were performed in order to demonstrate percentage identity to known bacteria (Altschul et al. 1997). DNA sequences were deposited into GenBank. Accession numbers are provided in Tables $2 \& 3$.

\section{RESULTS}

\section{Antibiotic properties of Acropora palmata mucus}

UV irradiation for $10 \mathrm{~min}$ at a wavelength of $302 \mathrm{~nm}$ inhibited the growth of all mucus-associated microbes for over 2 wk (data not shown). UV irradiation did not significantly affect CFUs per ml of associated microbes compared to non-irradiated control plates (data not shown).

Acropora palmata mucus collected in April 2005 inhibited growth of microbes from Florida Keys canal water 10-fold, and water column and African dust microbes roughly 4 -fold (Table 1 ). In addition, A. palmata mucus inhibited the growth of both Gram-positive and Gram-negative tester strains, including Bacillus subtilis (8-fold), Staphylococcus aureus (5-fold), Salmonella typhimurium (4-fold), and the Serratia marcescens white pox isolate PDL100 (2-fold; Table 1).

In contrast, mucus collected from apparently healthy areas of Acropora palmata in September 2005, during a bleaching event, had no significant inhibitory effects against the Serratia marcescens isolate PDL100, or microbes from Florida Keys canal water, African dust, or the water column (Table 1).

\section{Antibiotic production by coral associated bacteria}

Initial antibiotic testing of libraries containing 776 culturable bacteria strains collected from Acropora palmata throughout 2004 revealed that 155 isolates $(20 \%)$ inhibited the growth of 1 or more tester strains and $62(8 \%)$ of these isolates showed antibacterial activity against the Serratia marcescens isolate, PDL100 (data not shown).

\section{Selection for coral bacterial symbionts}

$$
\text { April } 2005 \text { sampling }
$$

Selection of putative coral symbionts from mucus dilutions plated onto mucus-treated media consistently resulted in 50- to 80-fold growth inhibition as compared to GASWA control medium (Fig. 1). From mucus-treated plates, 96 potential symbionts were selected, and designated as putative coral 'residents'; 95 bacteria were isolated from control plates and designated as putative 'visitors'. For comparison, 50 water column bacteria were isolated from GASWA control medium. Of the 96 resident bacteria tested for antibiotic production in this experiment, 39 (41\%) displayed antimicrobial activity against 1 or more tester strains. Of the 95 visitor bacteria tested for antibiotic production, $15(16 \%)$ produced antibiotic activity 
Table 1. Acropora palmata mucus inhibition assays. Inhibition of tester strains and potential sources of invasive microbes tested by plating mucus (M) collected at two different times of the year (with differing mean daily water temperatures) onto glycerol artificial seawater (GASWA) medium (G), followed by UV irradiation to inhibit out-growth of mucus-associated microbes. Various dilutions or concentrations of inoculum were plated onto each treatment medium (see 'Materials \& methods' for further details); dilutions producing between 200 and 400 colonies on control plates $(\mathrm{G}+\mathrm{UV})$ were compared to corresponding tester plates $(\mathrm{G}+\mathrm{M}+\mathrm{UV})$. Numbers based on mean $( \pm \mathrm{SD})$ of 4 plates for each experiment. Fold inhibition estimated by dividing experimental mean into control mean. $(-)=$ no data available for a particular source

\begin{tabular}{|c|c|c|c|c|c|c|}
\hline \multirow[t]{3}{*}{ Inoculum } & \multicolumn{3}{|c|}{-April 2005} & \multicolumn{3}{|c|}{ - September 2005} \\
\hline & \multicolumn{2}{|c|}{ No. of colonies } & \multirow{2}{*}{$\begin{array}{c}\text { Fold } \\
\text { inhibition }\end{array}$} & \multicolumn{2}{|c|}{ No. of colonies } & \multirow{2}{*}{$\begin{array}{c}\text { Fold } \\
\text { inhibition }\end{array}$} \\
\hline & $\begin{array}{c}\mathrm{G}+\mathrm{UV} \\
\text { (ctrl) }\end{array}$ & $\begin{array}{c}\mathrm{G}+\mathrm{M}+\mathrm{UV} \\
\quad(\text { expt) }\end{array}$ & & $\begin{array}{c}\mathrm{G}+\mathrm{UV} \\
\text { (ctrl) }\end{array}$ & $\begin{array}{c}\mathrm{G}+\mathrm{M}+\mathrm{UV} \\
(\operatorname{expt})\end{array}$ & \\
\hline Bacillus subtilis & $395( \pm 22)$ & $51( \pm 11)$ & 7.8 & - & - & - \\
\hline Staphylococcus aureus & $245( \pm 40)$ & $46( \pm 10)$ & 5.4 & - & - & - \\
\hline Salmonella typhimurium & $217( \pm 34)$ & $55( \pm 12)$ & 3.9 & - & - & - \\
\hline Serratia marcescens & $193( \pm 33)$ & $91( \pm 13)$ & 2.1 & $233( \pm 26)$ & $277( \pm 25)$ & -0.8 \\
\hline Water column & $305( \pm 29)$ & $76( \pm 7)$ & 4.0 & $188( \pm 27)$ & $231( \pm 14)$ & -0.8 \\
\hline Canal water & $269( \pm 24)$ & $27( \pm 9)$ & 10.0 & $328( \pm 28)$ & $274( \pm 20)$ & 1.2 \\
\hline African dust & $278( \pm 51)$ & $65( \pm 9)$ & 4.3 & $206( \pm 24)$ & $191( \pm 22)$ & 1.1 \\
\hline
\end{tabular}

against 1 or more tester strain. Bacterial numbers were condensed in group pools by dereplication based on antibiotic spectrum and by loss upon repeated subculturings. This reduced the residents pool to 30 viable strains, the visitors pool to 31 viable strains, and the water column pool to 25 viable strains. Genetic analysis based on partial sequencing of the 16S rDNA gene further dereplicated pools to 17, 17, and 12 unique isolates, from the residents, the visitors, and the watercolumn pools, respectively. Isolates that appeared genetically identical based on $16 \mathrm{~S}$ sequencing and colony morphology, but displayed different antibiotic spectra, were counted as unique. Genetic identities, antibiotic spectra, and GenBank accession numbers of this subset of isolates are shown in Table 2. Fig. 2 illustrates isolates that are unique within the residents, visitors, and water column pools.

\section{September 2005 sampling}

Selection of putative coral symbionts from apparently healthy areas of Acropora palmata during a late summer bleaching event resulted in no growth inhibition on mucus-treated media as compared to GASWA control media (Table 1). Nevertheless, for the purpose of comparison to spring 2005 selections, 21 isolates were chosen from mucus treated plates and were designated as putative coral residents. From the control plates, 27 bacteria were isolated and designated as putative visitors. For comparison, 59 water column isolates were chosen from GASWA control plates. Results show that A. palmata mucus collected during the September 2005 bleaching event lost the ability to select a discrete set of isolates (Table 3; Fig. 3). Genetic analysis based on partial sequencing of the 16S rRNA gene

Fig. 1. Selection scheme. Elkhorn coral Acropora palmata mucus dilutions (1:100) inoculated onto glycerol artificial seawater (GASWA) solid medium treated with coral mucus (left) or GASWA control medium (right). Bacterial growth was inhibited 50- to 80-fold on GASWA medium treated with mucus collected in spring 2005

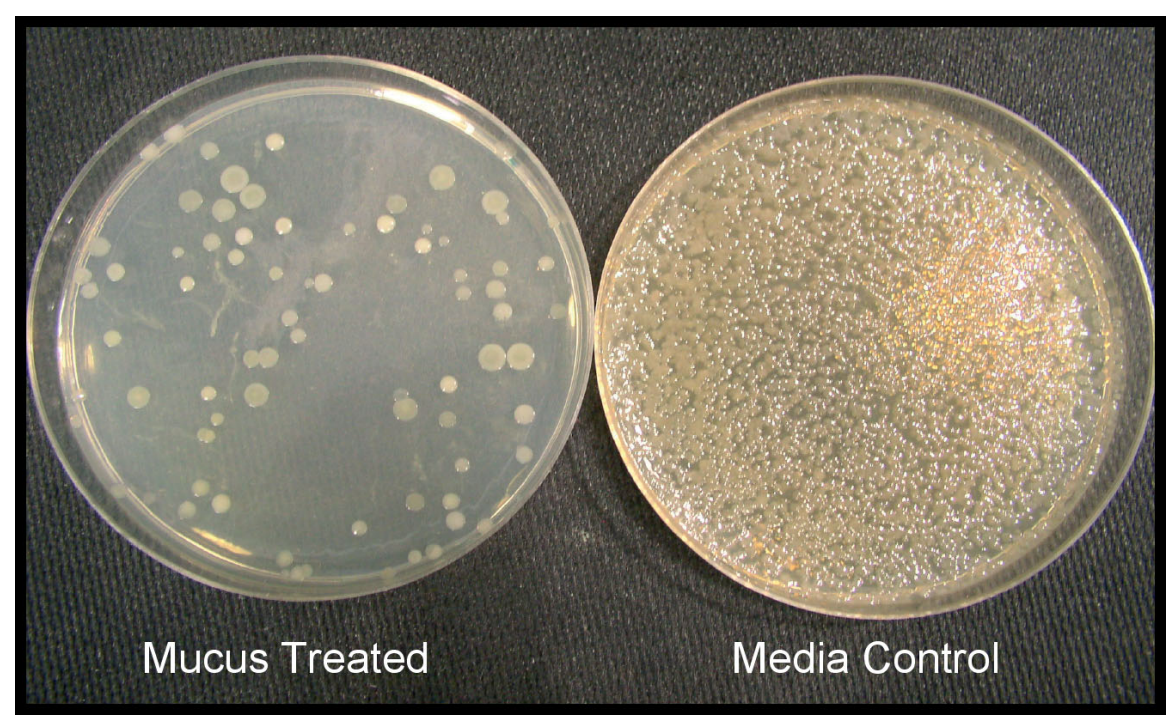


Table 2. Partial list of bacterial strains isolated from April 2005 selection for coral symbionts. For 2 mo prior to and during mucus sampling, mean daytime water temperature $=22$ to $25^{\circ} \mathrm{C}$. Not all isolates initially tested for antibiotic activity are included, due to loss of viability during repeated sub-culturing and/or frozen storage. Tester strains: methicillin-resistant Staphylococcus aureus (MRSA; ATCC 43300); methicillin-sensitive Staphylococcus aureus (MSSA; ATCC 29213); vancomycin-resistant Enterococcus (VRE); Bacillus subtilis (ATCC $6633 \mathrm{Km}$ resistant); Salmonella typhimurium (ATCC 6994); Enterococcus faecalis (ATCC 29212); Shigella (MicroGenomics); Escherichia coli O157; Agrobacterium tumefaciens; and coral pathogen Serratia marcescens strain PDL100. Residents: coral associates grown on mucus-treated experimental medium (GASWA+mucus+UV) as potential symbionts. Visitors: coral associates grown on control medium (GASWA+UV) as transient and/or potentially invasive microbes. Water column bacteria: water column isolates grown on control medium (GASWA). bp $=$ no. of base pairs sequenced. $\%$ ID $=$ percentage identity to closest-match bacterial representative in GenBank database. Isolates $=$ no. of similar strains isolated. $A B$ spectrum $=$ antibiotic spectrum, based on inhibition against listed tester strains. ZI = zone of inhibition, scored as distance (mm) from edge of colony to end of clearing zone. $(-)$ = antibiotic activity not detected. Accession \# = GenBank accession number of coral isolate

\begin{tabular}{|c|c|c|c|c|c|c|}
\hline Strain & $\mathrm{bp}$ & $\%$ ID & Closest match & Isolates & AB spectrum $(\mathrm{ZI})$ & Accession \# \\
\hline \multicolumn{7}{|c|}{ Residents } \\
\hline R1ma & 802 & 100 & Bacillus megaterium & 1 & B. subtilis (5) & DQ530511 \\
\hline $\mathrm{R} 1 \mathrm{mb}$ & 830 & 99 & Agrobacterium tumefaciens & 2 & - & DQ530512 \\
\hline R2te & 744 & 99 & Photobacterium phosphoreum & 2 & _ & DQ530513 \\
\hline R1m1 & 801 & 99 & Photobacterium damselae & 1 & - & DQ530514 \\
\hline $\mathrm{R} 1 \mathrm{~m} 2$ & 682 & 99 & Peligiobacter variabilis & 1 & - & DQ530515 \\
\hline $\mathrm{R} 1 \mathrm{~m} 3$ & 807 & 99 & Photobacterium sp. YS27-3 & 2 & - & DQ530516 \\
\hline R1t2 & 700 & 98 & Alteromonas sp. & 1 & - & DQ530517 \\
\hline R1t3 & 789 & 99 & Halomonas meridiana & 1 & _ & DQ530518 \\
\hline R1t4 & 690 & 100 & Halomonas meridiana & 2 & B. subtilis (1.5) & DQ530519 \\
\hline R1t6 & 682 & 100 & Photobacterium mandapumensis & 2 & B. subtilis (5) & DQ530520 \\
\hline R1t9 & 770 & 99 & Exiguonobacterium $s p$ & 1 & S. marscesens (1.5) & DQ530521 \\
\hline R1m5 & 804 & 100 & Photobacterium mandapumensis & 4 & - & DQ530522 \\
\hline $\mathrm{R} 2 \mathrm{~m} 1$ & 825 & 99 & Uncultured Alteromonas & 1 & S. marscesens (1.5) & DQ530523 \\
\hline $\mathrm{R} 2 \mathrm{~m} 2$ & 805 & 99 & Photobacterium leiognathis & 1 & S. marscesens (1.5) & DQ530524 \\
\hline R2t1 & 831 & 99 & Photobacterium damselae & 3 & S. marscesens (1.5) & DQ530525 \\
\hline $\mathrm{R} 2 \mathrm{t} 2$ & 816 & 99 & Photobacterium sp. YS27-3 & 2 & S. marscesens (1.5) & DQ530526 \\
\hline $\mathrm{R} 2 \mathrm{t} 3$ & 833 & 100 & Photobacterium sp YS27-3 & 3 & B. subtilis (1.5), S. marscesens (1) & DQ530527 \\
\hline \multicolumn{7}{|l|}{ Visitors } \\
\hline V1mt1 & 869 & 99 & Staphylococcus sp. & 2 & - & DQ530528 \\
\hline V2mt2 & 811 & 99 & Arctic sea ice bacterium & 2 & - & DQ530529 \\
\hline $\mathrm{V} 2 \mathrm{mt} 3$ & 866 & 99 & Agrobacterium sp. & 2 & - & DQ530530 \\
\hline VBR1 & 738 & 100 & Vibrio fortis & 2 & - & DQ530531 \\
\hline VBR2 & 720 & 100 & Vibrio shilonii & 2 & - & DQ530532 \\
\hline VBR5 & 806 & 99 & Enterovibrio coralii & 3 & - & DQ530533 \\
\hline VBR6 & 787 & 98 & Vibrio harveyii & 5 & - & DQ530534 \\
\hline VBR7 & 676 & 100 & Pseudoalteromonadaceae bacterium & 1 & $\begin{array}{l}\text { B. subtilis (8), MRSA (6), } \\
\text { MSSA (6), VRE (5), E. faecalis (5), } \\
\text { S. typhimurium (7), Shigella (7), } \\
\text { A. tumefaciens (6), E. coli }(4.5), \\
\text { S. marscesens (4) }\end{array}$ & DQ530535 \\
\hline VBR8 & 835 & 100 & Pseudoalteromonadaceae bacterium & 1 & - & DQ530536 \\
\hline VBR10 & 807 & 100 & Vibrio olivaceus & 3 & - & DQ530537 \\
\hline VBR12 & 654 & 99 & Vibrio nigripulchritudo & 1 & MRSA (1), MSSA (1) & DQ530538 \\
\hline VBR16 & 730 & 99 & Pseudoalteromonas sp. & 1 & B. subtilis & DQ530539 \\
\hline VBR19 & 797 & 100 & Pseudovibrio/Alpha proteobacterium & 1 & MRSA (4) & DQ530540 \\
\hline VBR22 & 798 & 100 & Alpha proteobacterium Z143-1 & 2 & $\begin{array}{l}\text { B. subtilis (2.5), MRSA (6), } \\
\text { MSSA (7), S. typhimurium (2), } \\
\text { Shigella (5), A. tumefaciens (4) }\end{array}$ & DQ530541 \\
\hline VBR27 & 648 & 96 & Vibrio hollisae & 1 & 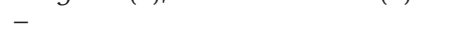 & DQ530542 \\
\hline VAP1-8 & 726 & 99 & Vibrio harveyii & 1 & B. subtilis (1), S. typhimurium (4) & DQ530543 \\
\hline VAP1-9 & 718 & 99 & Vibrio shilonii & 1 & B. subtilis (1), S. typhimurium (4) & DQ530544 \\
\hline \multicolumn{7}{|c|}{ Water column bacteria } \\
\hline W1 & 868 & 99 & Staphylococcus saprophyticus & 4 & - & DQ530545 \\
\hline W2 & 745 & 99 & Staphylococcus aureus & 2 & - & DQ530546 \\
\hline W3 & 837 & 99 & Agrobacterium sp. & 3 & - & DQ530547 \\
\hline W4 & 652 & 99 & Vibrio nigripulchritudo & 3 & - & DQ530548 \\
\hline W5 & 680 & 100 & Vibrio harveyii & 2 & - & DQ530549 \\
\hline W6 & 787 & 99 & Alpha proteobacterium & 3 & - & DQ530550 \\
\hline W7 & 875 & 99 & Pseudoalteromonas sp. & 1 & B. subtilis (3) & DQ530551 \\
\hline W8 & 573 & 99 & Pseudoalteromonas $\mathrm{sp}$. & 2 & - & DQ530552 \\
\hline W9 & 689 & 100 & Alpha proteobacterium & 1 & - & DQ530553 \\
\hline W10 & 401 & 99 & Vibrio alginolyticus & 1 & - & DQ530554 \\
\hline W11 & 717 & 99 & Kocuria sp. & 1 & - & DQ530555 \\
\hline W12 & 613 & 98 & Photobacterium eurosenbergii & 2 & _ & DQ530556 \\
\hline
\end{tabular}




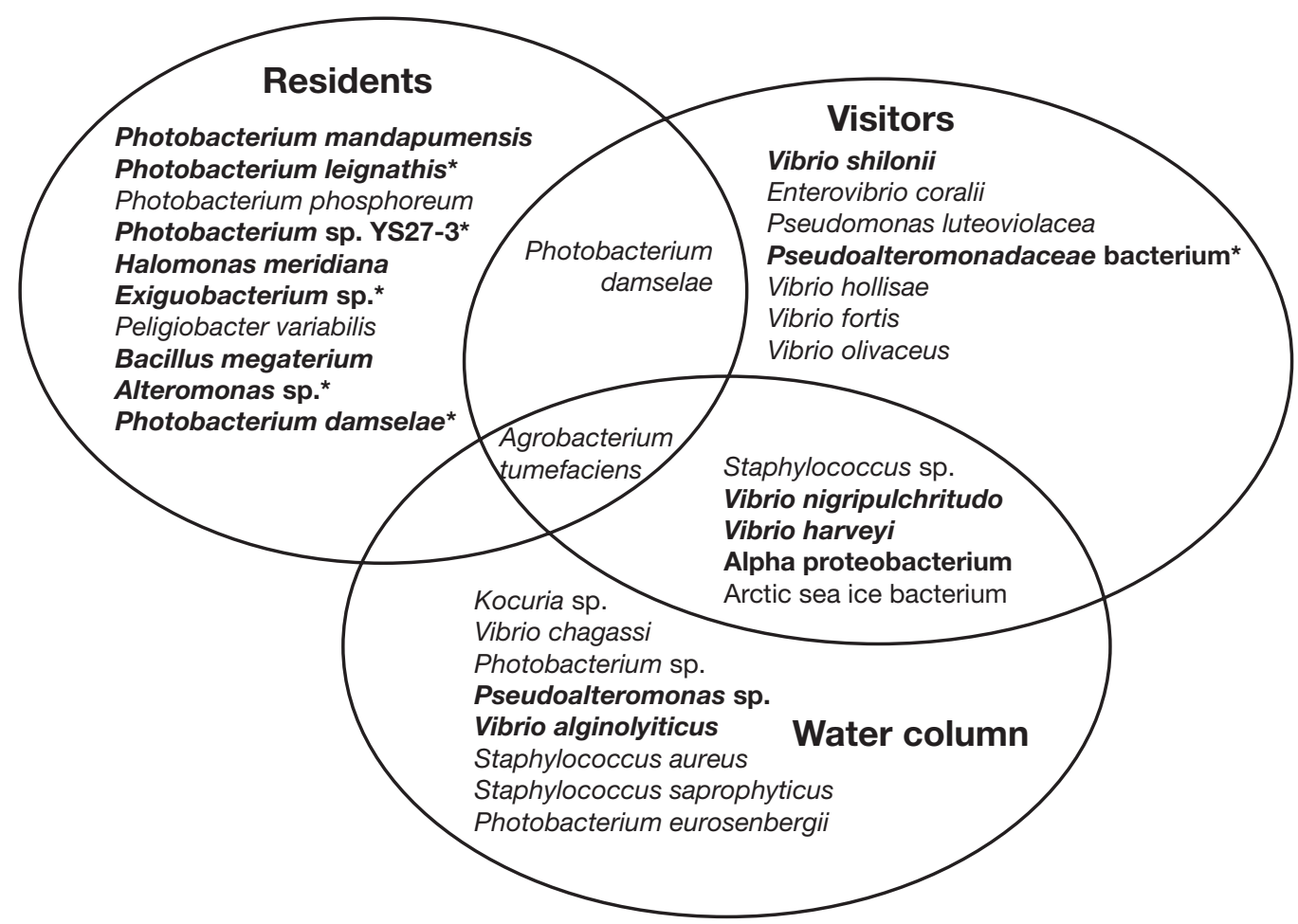

Fig. 2. Mucus selection scheme to enrich for coral symbionts (April 2005). Coral mucus sampled when mean daytime water temperature $=24^{\circ} \mathrm{C}$. Residents (top left): representative bacteria selected on mucus-treated medium (GASWA + mucus + UV) as putative coral symbionts. Visitors (top right): selected on control GASWA medium. Water column (bottom): selected from the water column on control medium. Overlap = bacteria common to different treatments and sources. Bold: bacteria producing an antimicrobial compound (residents, $41 \%$ total; visitors, $16 \%$ total; not all representatives shown). ${ }^{*}$ Bacteria producing antibiotic activity against Serratia marcescens strain PDL110

placed $100 \%$ of resident, $92 \%$ (22 of 24$)$ of visitor and $86 \%$ (49 of 58 ) of water-column isolates within the genus Vibrio. No resident isolates displayed antibiotic activity. Only one isolate, most similar to $V$. nigripulchritudo and common to both the visitor pool and seawater, had antibiotic activity (Table 3).

\section{Coral mucus regulates metabolic activities in a coral-associated bacterium}

One visitor isolate (VBR7), from Acropora palmata mucus produced a dark purple, non-diffusible, pigment on control plates, but lost the capability to produce the pigment when grown on $A$. palmata mucus-treated media (Fig. 4A). VBR7 also produced a broad-spectrum antibiotic (Table 2). Partial sequencing of the 16S rRNA gene identified this bacterium as 99\% identical to Pseudoalteromonaceae bacterium (Table 2). Antibiotic tests were performed on this isolate during pigment production and after pigment loss. Fig. 4B shows isolate VBR7 producing pigment on control media (left side, each panel) and after loss of pigment upon growth on coral mucus (right side, each panel). Each replica panel was overlaid with a different tester strain. The antibacterial compound associated with VBR7 was active against all Gram-positive and Gram-negative tester strains, with zones of inhibition ranging from 3 to $8 \mathrm{~mm}$. This indicated the presence of a readily diffusible, broad-spectrum antibiotic. Loss of pigment and antibiotic activity in VBR7 was also demonstrated when VBR7 was grown in the presence of mucus isolated from the gorgonian coral Pseudopterogorgia americana (collected from the Florida Keys), and the star boulder coral Montastraea faveolata (collected from both the Florida Keys and Flower Garden Banks).

\section{DISCUSSION}

While coral health appears to be declining world wide, the Caribbean elkhorn coral Acropora palmata has suffered the greatest losses, to the extent that it has recently been listed as a threatened species under the US Endangered Species Act. A. palmata appears particularly sensitive to stress and disease, although little is known of its physiological response to stressors 
Table 3. September 2005 (bleaching event) selection of coral symbionts. For 2 mo prior to and during mucus sampling, mean daytime water temperature $=28$ to $30^{\circ} \mathrm{C}$. Tester strains: methicillin-resistant Staphylococcus aureus (MRSA; ATCC 43300); methicillin-sensitive Staphylococcus aureus (MSSA; ATCC 29213); vancomycin-resistant Enterococcus (VRE); Bacillus subtilis (ATCC $6633 \mathrm{Km}$ resistant); Salmonella typhimurium (ATCC 6994); Enterococcus faecalis (ATCC 29212); Shigella (MicroGenomics); Escherichia coli O157; Agrobacterium tumefaciens; and coral pathogen Serratia marcescens strain PDL100. bp = no. of base pairs sequenced. \% ID = percentage identity to closest-match bacterial representative in GenBank database. Isolates = no. of similar strains isolated. $\mathrm{AB}$ spectrum = antibiotic spectrum, based on inhibition against listed tester strains. ZI = zone of inhibition, scored as distance $(\mathrm{mm})$ from edge of colony to end of clearing zone. $(-)=$ antibiotic activity not detected. Accession \# = GenBank accession number of coral isolate

\begin{tabular}{|c|c|c|c|c|c|c|}
\hline Strain & $\mathrm{bp}$ & $\%$ ID & Closest match & Isolates & AB spectrum (ZI) & Accession \# \\
\hline \multicolumn{7}{|c|}{ Coral associates grown on mucus-treated experimental media (GASWA+mucus+UV) } \\
\hline $\mathrm{R} 1$ & 693 & 100 & Vibrio harveyi & 6 & - & DQ521046 \\
\hline $\mathrm{R} 2$ & 693 & 99 & Vibrio coralllilyticus & 4 & - & DQ521047 \\
\hline R3 & 849 & 100 & Vibrio alginolyticus & 4 & - & DQ521048 \\
\hline $\mathrm{R} 4$ & 692 & 100 & Vibrio campbelli & 2 & - & DQ521049 \\
\hline R5 & 690 & 98 & Vibrio shilonii & 1 & - & DQ521050 \\
\hline R6 & 682 & 99 & Vibrio neptunius & 1 & - & DQ521051 \\
\hline $\mathrm{R} 7$ & 692 & 99 & Vibrio sp. PH1 & 1 & - & DQ521052 \\
\hline R8 & 692 & 100 & Vibrio chagasii & 1 & - & DQ521053 \\
\hline R9 & 683 & 99 & Vibrio probioticus & 1 & - & DQ521054 \\
\hline \multicolumn{7}{|c|}{ Coral mucus associates grown on control media (GASWA+UV) } \\
\hline V1 & 690 & 100 & Vibrio corallilyticus & 4 & - & DQ521055 \\
\hline $\mathrm{V} 2$ & 720 & 98 & Vibrio sp. PH1 & 4 & - & DQ521056 \\
\hline V3 & 833 & 99 & Vibrio alginolyticus & 2 & - & DQ521057 \\
\hline V4 & 691 & $98-99$ & Vibrio shilonii & 2 & - & DQ521058 \\
\hline V5 & 694 & 99 & Vibrio harveyi & 3 & - & DQ521059 \\
\hline V6 & 691 & 99 & Vibrio sp. ME2-03 & 3 & - & DQ521060 \\
\hline V7 & 690 & 100 & Vibrio sp. HB-8 & 2 & - & DQ521061 \\
\hline V8 & 683 & 100 & Vibrio olivaceus & 1 & - & DQ521062 \\
\hline V9 & 690 & 100 & Vibrio sp. A356 & 1 & - & DQ521063 \\
\hline V10 & 689 & 100 & Vibrio parahaemolyticus & 1 & - & DQ521064 \\
\hline V11 & 554 & 98 & Shewanella sp. & 1 & - & DQ521065 \\
\hline V12 & 684 & 99 & Vibrio nigripulchritudo & 1 & MSSA (1), MRSA (1) & DQ521066 \\
\hline V13 & 676 & 100 & Photobacterium mandapamensis & 2 & - & DQ521067 \\
\hline \multicolumn{7}{|c|}{ Water column isolates grown on control media (GASWA) } \\
\hline W1 & 693 & 100 & Vibrio harveyi & 9 & - & DQ521068 \\
\hline W2 & 691 & 98 & Vibrio shilonii & 5 & - & DQ521069 \\
\hline W3 & 689 & 100 & Vibrio ponticus & 5 & - & DQ521070 \\
\hline W4 & 692 & 99 & Vibrio sp. PH1 & 5 & - & DQ521071 \\
\hline W5 & 690 & 99 & Vibrio nigripulchritudo & 5 & MSSA (1), MRSA (1) & DQ521072 \\
\hline W6 & 823 & 99 & Vibrio olivaceus & 4 & - & DQ521073 \\
\hline W7 & 690 & $98-99$ & Vibrio neptunius & 3 & - & DQ521074 \\
\hline W8 & 700 & 97 & Shewanella sp. $L-10$ & 3 & - & DQ521075 \\
\hline W9 & 686 & 100 & Vibrio campbelli & 3 & - & DQ521076 \\
\hline W10 & 609 & 99 & Vibrio corallilyticus & 2 & - & DQ521077 \\
\hline W11 & 689 & 100 & Photobacterium mandapamensis & 2 & - & DQ521078 \\
\hline W12 & 690 & 100 & Vibrio alginolyticus & 3 & - & DQ521079 \\
\hline W13 & 675 & 96 & Photobacterium ganghwensis & 2 & - & DQ521080 \\
\hline W14 & 823 & 98 & Vibrio sp. BL1-41 & 1 & - & DQ521081 \\
\hline W15 & 694 & 100 & Vibrio sp. YASM15 & 1 & - & DQ521082 \\
\hline W16 & 609 & 99 & Vibrio gallicus & 1 & - & DQ521083 \\
\hline W17 & 607 & 98 & Vibrio sp. Absa37 & 1 & - & DQ521084 \\
\hline W18 & 645 & 98 & Vibrio sp. ME2-03 & 1 & - & DQ521085 \\
\hline W19 & 691 & 100 & Vibrio sp. HB-8 & 1 & - & DQ521086 \\
\hline W20 & 696 & 98 & Pseudoalteromonas sagamiensis & 1 & - & DQ521087 \\
\hline W21 & 607 & 100 & Rhodobacteraceae sp. & 1 & - & DQ521088 \\
\hline
\end{tabular}




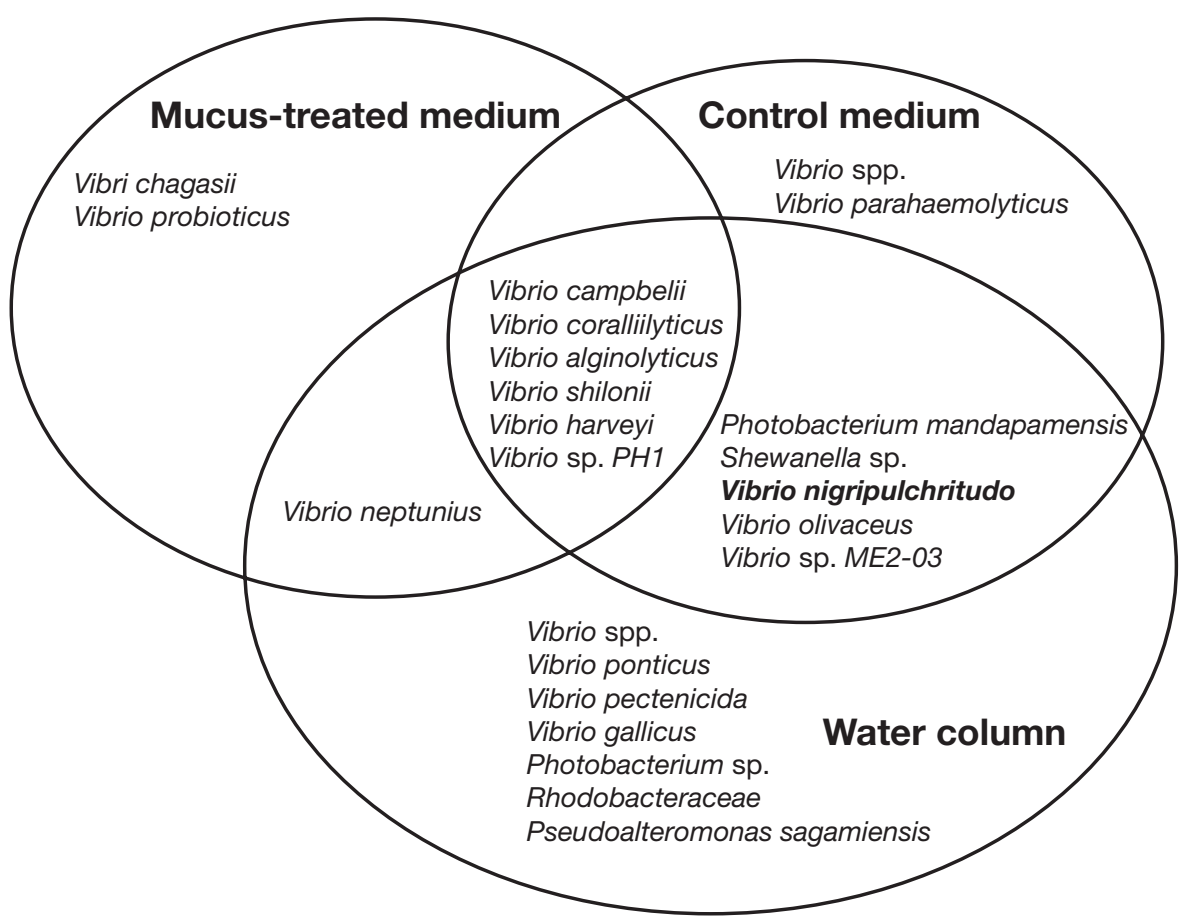

Fig. 3. Mucus selection scheme (September, 2005). Coral mucus sampled when mean daytime water temperature $=30^{\circ} \mathrm{C}$. Representative bacteria selected on mucus-treated medium (GASWA + mucus + UV; top left); control medium (GASWA + UV; top right); or water column bacteria isolated on control medium (GASWA; bottom). Note that applied selection scheme falls apart (cf. Fig. 2), with loss of diversity in all treatments and sources tested; high incidence of Vibrio spp., including numerous vibrios implicated in coral bleaching and opportunistic diseases of marine organisms. Overlap = bacteria common to different treatments and sources. Bold = bacteria producing an antibacterial compound

(Antonius 1977, 1981, Gladfelter et al. 1977, Bruckner 2002, Precht 2004, Sutherland \& Ritchie 2004). Some suggested sources of coral decline include increased sea surface temperatures, coastal degradation, pollution, diseases, ecosystem imbalance caused by anthropogenic influences, and the synergistic effect of multiple stressors (Harvell et al. 2002, Rosenberg \& Ben-Haim 2002, Sutherland et al. 2004). One possible explanation for an increased incidence of coral diseases is stress-induced susceptibility to opportunistic microbes trapped in the coral mucus. Numerous sources of pathogenic microbes have been suggested
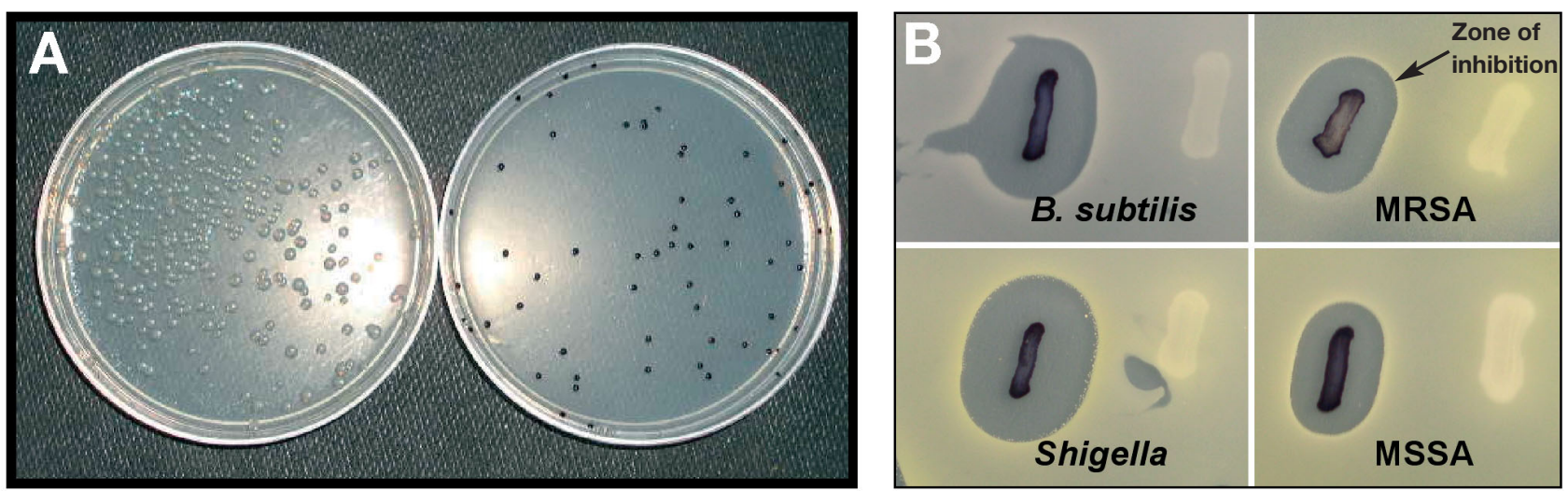

Fig. 4. Coral mucus inactivates metabolic properties of potentially invasive bacterium. (A) Putative 'visitor' bacterium VBR7 isolated from elkhorn coral Acropora palmata mucus produced a deep purple pigment when grown on GASWA control medium (right) but not when grown on medium treated with mucus collected from A. palmata (left), scleractinian coral Montastrea faveolata, or gorgonian coral Pseudopterogorgia americana (not shown). (B) Each panel shows antibiotic activity of replicas of isolate VBR7 before (control medium; left side, each panel) and after pigment loss on mucus treated medium (right side, each panel). Tester strains used were Bacillus subtilis, methicillin-resistant Staphylococcus aureus (MRSA), methicillin-sensitive $S$. aureus (MSSA), and Shigella. Arrow: MRSA growth inhibition zone produced by VBR7 
as possible threats to the health of corals in the Florida Keys. These include canal water, which is a source of human enteric bacteria such as Serratia marscesens (Patterson et al. 2002); African dust, hundreds of millions of tons of which are transported to the Caribbean each year along with associated bacteria, fungi and viruses (Garrison et al. 2003); and water column microbes that may become opportunistic under conditions of increased temperature and nutrient load.

\section{Acropora palmata mucus as a biochemical defense}

This study shows that mucus collected from Acropora palmata has antibiotic activity against (1) Grampositive and Gram-negative bacteria, (2) a number of potentially invasive microbes (including microbes from Florida Keys canal water, African dust, and surrounding sea water), and (3) a pathogen implicated in white pox disease of $A$. palmata. This result suggests that healthy A. palmata employ a biochemical mechanism for disease resistance that may act as a primary defense against pathogens. In contrast, mucus collected from $A$. palmata during a period of increased water temperature did not show significant antibiotic activity against the same suite of sources and tester strains, suggesting that the protective mechanism employed by A. palmata is lost when temperatures increase. This observation suggests a mechanism to the hypothesis that increased temperatures lower coral resistance, resulting in an increased susceptibility to disease.

\section{Beneficial coral bacteria}

Both culture-dependent and independent methods have been used to understand microbial communities on the surface of corals (reviewed in Brown \& Bythell 2005). Both methods show that corals favor specific populations of bacterial associates that are predicted to be mutualistic with the coral host (Ritchie \& Smith 1997, 2004, Rohwer et al. 2002). While culture-based methods are biased toward the small percentage of microbial associates that are able to be cultivated in the laboratory, culture-independent studies based on 16S rDNA are limited in their prediction of compound production and metabolic potential of coral-associated bacteria. This study did not attempt to address total microbial community structure of Acropora palmata, but focused on a subset of marine bacteria cultured under specific growth conditions to investigate a potential bacterial contribution to the antibiotic activity seen in coral mucus.

Initial testing of culturable bacteria collected from A. palmata mucus throughout the course of 2004 illustrated that roughly $20 \%$ displayed antibacterial activities. This result suggests a potential role for coral bacterial associates in the production of mucusassociated antibiotic activity. In situ antibiotic production by associated bacteria is a means of securing a niche by controlling microbial populations competing for the same resources (Neilson et al. 2000, Rao et al. 2005). The level of antibiotic contribution by these bacteria in situ remains to be determined.

\section{Selection for coral symbionts}

Coral mucus traps particles and microbes that pass by in the water column (Wild et al. 2004). Therefore, attempts at understanding the importance of coralassociated microbial communities may be misleading due to the fact that coral mucus is indiscriminate, retaining microbes from a fluctuating water mass that may not be present in the water column at the time of collection. These dynamic fluctuations include coastal upwelling, countless local and regional influences, and local flora and fauna. Thus, many microbes trapped in coral mucus are less likely to be true 'residents,' or mutualists, but rather 'visitors' consisting of transient commensal microorganisms that do no good or harm, or organisms that can potentially become opportunistic under the right conditions.

The phylogenetic approaches used in most comprehensive analyses of unculturable coral microbes provide information on the identity of microbes present, but very little information relative to microbial interactions, or information necessary for the elucidation of true coral residents (microbes beneficial to the coral host, zooxanthellae, or other resident microbes). Here, a culture-based approach was developed to address this challenge by using sterile coral mucus as a selection medium for coral symbionts: bacteria that benefit from nutrients available on the coral surface while providing a benefit to the coral in return. This approach is based on the hypothesis that true coral symbionts will be resistant to the antibiotic properties of Acropora palmata mucus, while many trapped bacteria may be sensitive to the bacteriocidal, or bacteriostatic, properties in coral mucus.

This selection scheme was first applied using Acropora palmata mucus collected in spring 2005 under temperatures that were sustained at 22 to $24^{\circ} \mathrm{C}$ for 2 mo prior to sampling. Bacteria isolated on mucustreated plates as putative symbionts were designated as coral 'residents,' while bacteria isolated from control media were designated as potential 'visitors,' or transient bacteria trapped from the water column. Fig. 2 illustrates that the vast majority of bacteria cultured, using either mucus-treated selection media or control 
media, belonged to the $\gamma$-proteobacteria. Members of this group are abundant on corals and have been identified using a range of methods, including culturebased (Ritchie \& Smith 2004), molecular (Rohwer et al. 2002), and fluorescence in situ hybridization and spectral imaging (Ainsworth et al. 2006). Therefore, I think that this subset of culturable associates represents a valid group for the study of symbiotic interactions.

Results show that the mucus-based selection method enriched for Photobacterium spp. (60\%), Halomonas spp. $(10 \%)$, and a range of bacterial species that have antibiotic activities (Table 2, Fig. 2). The significance of Photobacterium and Halomonas spp. enrichment is not clear, although a subset of each is shown to produce antibiotics (Table 2). It is possible that these bacteria additionally play a role in the health of the coral holobiont via production of vitamins or cofactors necessary for the growth of beneficial bacteria, or by providing other regulatory compounds. In addition, some strains designated as coral residents were active against the Serratia marcescens PDL100 coral disease pathogen. That this method enriched for bacteria that produce antibiotics provides additional support for a bacterial contribution to the antibiotic activity of coral mucus while providing a novel method for the enrichment of marine bioactive compounds.

Bacteria isolated as visitors are representative of bacteria documented in earlier studies, including a subset of Vibrio species consistently found in association with healthy corals (Ritchie \& Smith 1995a,b, 2004). As partial sequencing of the $16 \mathrm{~S}$ gene is not sufficient for a thorough identification of members of the genus Vibrio, these isolates will require further genetic delineation. Table 2 shows that there is a higher percentage of vibrios $(48 \%)$ when comparing control plates to the coral mucus selection scheme (no vibrios). A subset of vibrios isolated from control plates (visitor microbes Vibrio shilonii and Enterovibrio sp.) are most similar to species associated with coral bleaching in the Mediterranean Sea and in the Great Barrier Reef (Kushmaro et al. 2001, Thompson et al. 2005), suggesting that these bacterial species are ubiquitous in tropical oceans. Several visitor and water column isolates produced antibiotics. Isolate VBR7 produced a broad spectrum antibiotic with large zones of inhibition and isolate VAP1-9, which displayed 99\% identity to Vibrio shilonii, exhibited antibiotic activity against 2 Gram-positive tester strains. These isolates may represent bacteria capable of becoming opportunistic under conditions of coral stress.

Collectively, these results suggest that coral mucus provides a hostile environment for some bacteria and a nurturing environment for others, illustrating that the mucus plays an important role in structuring microbial communities on the coral surface. The use of coral mucus as a selection medium is experimental. It is possible that UV sterilization alters the composition of the mucus in a manner not addressed by the UV controls. However, the results using UV irradiated summer mucus, described below, argue against significant alteration of the mucus by UV treatment.

\section{Loss of antibiotic activity and shift to Vibrio spp. during a summer bleaching event}

The antibiotic properties of coral mucus, and the potential for mucus to select a discrete set of commensal bacteria, were lost at increased temperatures during a bleaching event (Table 3; Fig. 3). Mucus was taken from corals sustained at a mean daytime sea surface temperature of 28 to $30^{\circ} \mathrm{C}$ for 2 mo prior to collection. Vibrios were the predominant species cultured from the mucus of apparently healthy Acropora palmata tissue during this event. Vibrios were also predominant in the water column during this period, representing $85 \%$ of the cultured isolates (Table 3). Less than $2 \%$ of bacteria isolated from the surface of A. palmata during this period produced antibiotic activity. These findings illustrate a temporal shift in the protective qualities of coral mucus, and a composition shift from beneficial bacteria to vibrio dominance under conditions of increased temperature. Vibrios present during this event included those involved in temperature dependent bleaching of corals, such as Vibrio shilonii (=V. shiloi; Kushmaro et al. 2001) and V. coralliilyticus (= V. coralyticus; Ben-Haim et al. 2003) as well as numerous vibrios known to be opportunistic to other marine organisms (Table 3). These findings are consistent with a shift of the equilibrium between Pseudomonas spp. and Vibrio spp. in healthy corals, to vibrio dominance when corals are bleached (Ritchie \& Smith 1995a, 2004). However, as mucus was collected from apparently healthy coral tissue, and not bleached tissue, this provides evidence that a community shift to vibrio dominance may occur prior to zooxanthellae loss.

During bleaching, coral mucus production changes in quality and can decrease in quantity, depending on the cellular damage caused by the environmental factor(s) that initiated bleaching (Lasker et al. 1984, Glynn et al. 1986). Thus, microbes that depend on particular substrates in healthy mucus may be reduced in number when these substrates are no longer available. One model that addresses coral bleaching and disease susceptibility is that antimicrobial properties of coral mucus are compromised by temperature-dependent alteration of resident microbes, or other factors influencing antibiotic activity, followed by an overgrowth of vibrios, which are abundant in the water column during warmer months. A similar model is that bene- 


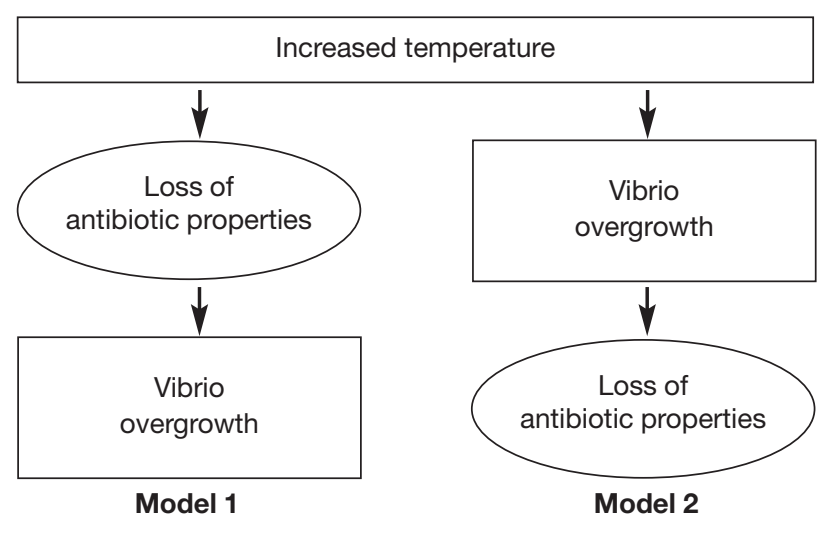

Fig. 5. Models of bacterial overgrowth on coral surfaces. In Model 1, rising water temperature compromises antibiotic production by the coral holobiont, either by affecting antibiotic production by the coral or by affecting composition and/or activity of resident microbiota. This results in opportunistic overgrowth of transient microbes in coral mucus, increasing the probability of bleaching or disease. In Model 2, overgrowth by transient microbes out-competes the resident population of microbiota, with subsequent loss of antibiotic activity associated with coral mucus. This model requires additional evidence that resident coral-associated microbes contribute significantly to antibiotic activity described for coral mucus

ficial microbes are simply out-competed by vibrios, many of which thrive under conditions of increased temperature (Lipp et al. 2002, Rosenberg \& Ben-Haim 2002, Thompson et al. 2005). Both models (Fig. 5) are supported by observations in this study and others. Kuntz et al. (2005) reported that growth stimulation of bacterial communities present on corals may directly result in coral mortality. In addition, it has been shown that 4 vibrio strains, inoculated as a group, were able to cause signs of yellow band disease when temperatures were increased (Cervino et al. 2004).

Another possible mechanism that supports both models is cooperation among similar bacteria (Foster 2005). This theory is distinct from a one-pathogen model for coral bleaching by Vibrio species (Kushmaro et al. 2001, Ben-Haim et al. 2003), in that it is based on a bacterial version of kin-selection theory, where similar bacteria are able to co-operate to secure a niche because they share like genes (Foster 2005). This may also apply to vibrios associated with corals. In this scenario, vibrios may compete for space on the coral surface, reducing relatedness among beneficial surface bacteria by sharing similar gene products involved in securing a niche (such as feeding enzymes and virulence factors, among others). The result is the swamping of resident beneficial microbes, the initiation of coral bleaching and, perhaps ultimately, an increase in disease susceptibility.

Regardless of the precise ordering of events, during times of increased sea surface temperature, corals are more susceptible to disease (Rosenberg \& Ben-Haim 2002), which is demonstrated in this study to be correlated with a loss of a protective function provided in the coral mucus and an increase in the number of vibrios, both in the water column and on the surface of apparently healthy coral tissue. These observations may offer further clarification for the increase in coral disease incidence that occurs following bleaching events (Causey 2001, Harvell et al. 2002, Weil et al. 2006).

\section{Undocumented function of coral mucus}

While studying the interaction of Acropora palmata mucus with potentially invasive microbes, it was noted that one visitor isolate (VBR7), a Pseudoalteromonaceae bacterium isolated from $A$. palmata mucus, produced a dark purple, non-diffusible pigment on control plates, but lost the ability to produce the pigment when grown on A. palmata mucus-treated media (Fig. 4a). This isolate was initially shown to produce a powerful, broad-spectrum antibiotic (Table 2). As pigment production is often correlated with antibiotic activity (Ritchie, pers. obs.), antibiotic tests were performed on this isolate both during pigment production and after pigment loss. Results showed that VBR7 produced a broad-spectrum, readily diffusible antibiotic when grown on control media, during pigment expression. Conversely, antibiotic activity was absent when the pigment was lost in this strain. Loss of pigment production and antibiotic activity in VBR7 was also demonstrated when VBR7 was grown in the presence of $A$. palmata mucus collected during summer months, mucus isolated from the gorgonian coral Pseudopterogorgia americana (collected from the Florida Keys), and mucus from the star boulder coral Montastrea faveolata (collected from both the Florida Keys and Flower Garden Banks). This result illustrates that a component universal to coral mucus, independent of species, location, and season, is capable of inhibiting pigment and antibiotic production associated with VBR7. The production of cell signaling molecules by many microbes regulates bacterial processes in a population density-dependent manner (Miller \& Bassler 2001, Teplitski et al. 2004). This type of communication, called 'quorum sensing,' is common in bacterial biofilms and regulates processes such as adhesion, antibiotic production, and virulence (Miller \& Bassler 2001). Quorum sensing molecules, if present in coral mucus, could result in the pigment and antibiotic suppression seen in VBR7. Although further studies will reveal whether these regulatory processes within the mucus are attributed to the coral, zooxanthellae, or coral associated bacteria, the regulation of bacterial 
gene expression by mucus is likely to play a significant role in both the determination of microbial community structure and in the establishment of pathogenic bacteria.

\section{CONCLUSIONS}

In this study, Acropora palmata mucus was shown to have antibiotic properties that are likely to play a role in ordering beneficial microbial communities on the coral surface. In addition, mucus from healthy $A$. palmata harbors bacteria capable of producing antibiotics, implicating a microbial contribution to the protective properties of coral mucus. Coral mucus inactivated pigment production and antibiotic activity in a mucus-associated bacterium, illustrating an undocumented role of coral mucus in the control of associated microbes. Mucus-associated antibiotic activity was reduced when mucus was collected during a period of increased sea surface temperature. This finding suggests a seasonal variability in the protective qualities of coral mucus that may result in increased susceptibility to bleaching and disease. Beneficial coral bacteria were replaced by Vibrio spp. during this event, which resulted in a loss of antibiotic producing bacteria on coral surfaces. Future studies will reveal temporal and environmental changes on the coral surface, and the precise role of coral mucus and beneficial microbes in coral health and disease susceptibility.

Acknowledgements. This work was funded by NOAA grants NCND6012-5-00033, NCND60111-5-00013, the Edith and Curtis Munson Foundation, and Mote Marine Laboratory. Collections were obtained via permit FKNMS 2004-015 (Florida Keys National Marine Sanctuary) and FGBNMS permit 2005-006 (Flower Garden Banks National Marine Sanctuary). I thank E. Bartels and staff of the FKNMS for boat and sampling support, V. Palubok for laboratory support, V. Garrison (USGS) for kindly supplying Mali desert soil, and V. Dartois (Microgenomics) for providing tester strains. I am most grateful to B. Causey, S. Gittings, M. Hay, B. Keller, E. Peters, J. Pringle, K. Sharpe, G. Smith, M. Teplitski, J. Thurmond and 4 anonymous reviewers for helpful discussions and/or improvements to the manuscript.

\section{LITERATURE CITED}

Ainsworth TD, Fine M, Blackall LL, Hoegh-Guldberg O (2006) Fluorescence in situ hybridization and spectral imaging of coral-associated bacterial communities. Appl Environ Microb 72:3016-3020

Altschul SF, Madden TL, Schäffer AA, Zhang J, Zhang Z, Miller W, Lipman DJ (1997) Gapped BLAST and PSIBLAST: a new generation of protein database search programs. Nucleic Acids Res 25:3389-3402

Antonius A (1977) Coral mortalities in reefs: a problem for science and management. Proc 3rd Int Coral Reef Symp $1: 617-623$
Antonius A (1981) Coral reef pathology: a review. Proc 4th Int Coral Reef Symp 2:3-6

Armstrong E, Yan L, Boyd KG, Wright PC, Burgess JG (2001) The symbiotic role of marine microbes on living surfaces. Hydrobiologia 461:37-40

Ben-Haim Y, Thompson FL, Thompson CC, Cnockaert MC, Hoste B, Swings J, Rosenberg E (2003) Vibrio coralliilyticus sp. nov., a temperature-dependent pathogen of the coral Pocillopora damicornis. Int J Syst Evol Micr 53: 309-315

Brown BE, JC Bythell (2005) Perspectives on mucus secretion in reef corals. Mar Ecol Prog Ser 296:291-309

Bruckner AW (2002) Priorities for effective management of coral reefs. NOAA Tech Memo NMF-OPR-22 August 2002. Available at: www.icriforum.org/docs/man_priorities_coral_ diseases.pdf

Burkholder PR, Burkholder LM (1958) Antimicrobial activity of horny corals. Science 127:1174-1175

Castillo I, Lodeiros C, Nunez, M, Campos I (2001) In vitro evaluation of antibacterial substances produced by bacteria isolated from different marine organisms. Rev Biol Trop 49:1213-1222

Causey BD (2001) Lessons learned from the intensification of coral bleaching from 1980-2000 in the Florida Keys, USA. In: Salm RV, Coles SL (eds) Coral bleaching and marine protected areas: Proc Workshop 'Mitigating coral bleaching impact through MPA design' (Bishop Museum, Honolulu, HI). Asia Pacific Coastal Marine Program Report \# 0102, The Nature Conservancy. Available at: www. conserveonline.org/docs/2001/10/CoralBleechingMPAsWorkshop.pdf

Cervino JM, Hayes RL, Polson SW, Polson SC, Goreau TJ, Martinez RJ, Smith GW (2004) Relationship of Vibrio species infection and elevated temperatures to yellow blotch/band disease in Caribbean corals. Appl Environ Microbiol 70:6855-6864

Elyakov GB, Kuznetsova T, Mikhailov VV, Maltsev II, Voinov VG, Fedoreyev SA (1991) Brominated biphenyl ethers from a marine bacterium associated with the sponge Dysidea sp. Experientia 47:632-633

Foster KR (2005) Hamiltonian medicine: why the social lives of bacteria matter. Science 308:1269-1270

Garrison VH, Shinn EA, Foreman WT, Griffin RD and 6 others (2003) African and Asian dust: from desert soil to coral reef. Bioscience 53:469-480

Geffen Y, Rosenberg E (2005) Stress-induced rapid release of antibacterials by scleractinian corals. Mar Biol 146: 931-935

Gil-Turnes MS, Hay ME, Fenical W (1989) Symbiotic marine bacteria chemically defend crustacean embryos from a pathogenic fungus. Science 246:116-118

Gladfelter WB, Gladfelter EH, Monahan RK, Ogden JC, Dill RF (1977) Coral destruction: environmental studies of Buck Island Reef National Monument. Biosphere Reserve Res Rep No. 6, US National Park Service, US Dept of Interior, Washington, DC

Glynn PW, Peters EC, Muscatine L (1986) Coral tissue microstructure and necrosis: relation to catastrophic coral mortality in Panama. Dis Aquat Org 1:29-37

Harvell CD, Kim K, Burkholder JM, Colwell RR and 7 others (1999) Emerging marine diseases-climate links and anthropogenic factors. Science 285:1505-1510

Harvell CD, Mitchell CE, Ward JR, Altizer S, Dobson AP, Ostfeld RS, Samuel MD (2002) Climate warming and disease risks for terrestrial and marine biota. Science 296: $2158-2162$

Holmstrom C, Rittschof D, Kjelleberg S (1992) Inhibition of 
settlement by larvae of Balanus amphitrite and Ciona intestinalis by a surface-colonizing marine bacterium. Appl Environ Microb 58:2111-2115

Kelman D, Kushmaro A, Loya Y, Kashman Y, Benayahu Y (1998) Antimicrobial activity of a Red Sea coral, Parerythropodium fulvum fulvum: reproductive and developmental considerations. Mar Ecol Prog Ser 169:87-95

Kelman D, Kashman Y, Rosenberg E, Kushmaro A, Loya Y (2006) Antimicrobial activity of Red Sea corals. Mar Biol 149:357-363

Kim K (1994) Antimicrobial activity in gorgonian corals (Coelenterata, Octocorallia). Coral Reefs 13:75-80

Koh EG (1997) Do scleractinian corals engage in chemical warfare against microbes? J Chem Ecol 23:379-398

Kuntz NM, Kline DI, Sandin SA, Rohwer F (2005) Pathologies and mortality rates caused by organic carbon and nutrient stressors in three Caribbean coral species. Mar Ecol Prog Ser 294:173-180

Kushmaro A, Banin E, Loya Y, Stackebrandt E, Rosenberg E (2001) Vibrio shiloi sp. nov., the causative agent of bleaching of the coral Oculina patagonica. Int J System Evol Microbiol 51:1383-1388

Lasker HR, Peters EC, Coffroth MA (1984) Bleaching of reef coelenterates in the San Blas Islands, Panama. Coral Reefs 3:183-190

Lipp E, Huq A, and Colwell RR (2002) Effects of global climate on infectious disease: the Cholera Model. Clin Microbiol Rev 15:757-770

Miller MB, Bassler BL (2001) Quorum sensing in bacteria. Annu Rev Microbiol 55:165-199

Neilson AT, Tolker-Neilsen K, Barken K, Molin S (2000) Role of commensal relationships on the spatial structure of a surface-attached microbial consortium. Environ Microbiol 2:59-68

Patterson KL, Porter JW, Ritchie KB, Smith GW, Polson SW (2002) Etiology of white pox, a lethal disease of the Caribbean elkhorn coral, Acropora palmata. Proc Natl Acad Sci USA 99:8725-8730

Precht WF, Robbart ML, Aronson RB (2004) The potential listing of Acropora species under the US Endangered Species Act. Mar Poll Bull 49:534-536

Rao D, Webb JS, Kjelleberg S (2005) Competitive interactions in mixed-species biofilms containing the marine bacterium Pseudoalteromonas tunicata. Appl Environ Microb 71:1729-1736

Ritchie KB, Smith GW (1995a) Preferential carbon utilization by surface bacterial communities from water mass, normal, and white-band diseased Acropora cervicornis. Mol Mar Biol Biotech 4:345-352

Ritchie KB, Smith GW (1995b) Carbon-source utilization patterns of coral-associated marine heterotrophs. J Mar Biotechnol 3:105-107

Editorial responsibility: Charles Birkeland (Contributing Editor), Honolulu, Hawaii, USA
Ritchie KB, Smith GW (1997) Physiological comparisons of bacteria from various species of scleractinian corals. Proc 8th Int Symp Reef Studies 1:521-526

Ritchie KB, Smith GW (2004) Microbial communities of coral surface mucopolysaccharide layers. In: Rosenberg E, Loya $\mathrm{Y}$ (eds) Coral health and disease. Springer-Verlag, Berlin, p 259-263

Rohwer F, Seguritan V, Azam F, Knowlton N (2002) Diversity and distribution of coral-associated bacteria. Mar Ecol Prog Ser 243:1-10

Rosenberg E, Ben-Haim Y (2002) Microbial diseases of corals and global warming. Environ Microbiol 4:318-326

Slattery M, McClintock JB, Heine JN (1995) Chemical defenses in Antarctic soft corals: evidence for anti-fouling compounds. J Exp Mar Biol Ecol 190:61-77

Slattery M, Hamann MT, McClintock JB, Perry TL, Puglisi MP, Yoshida WY (1997) Ecological roles for water-borne metabolites from Antactic soft corals. Mar Ecol Prog Ser 161:133-144

Smith GW, Hayasaka SS (1982) Nitrogenase activity associated with Halodule wrightii roots. Appl Environ Microb 43:1244-1248

Sutherland KP, Porter JP, Torres C (2004) Disease and immunity in Caribbean and Indo-Pacific zooxanthellate corals Mar Ecol Prog Ser 266:273-302

Sutherland KP, Ritchie KB (2004) White pox disease of the Caribbean elkhorn coral, Acropora palmata. In: Rosenberg E, Loya Y (eds) Coral health and disease. SpringerVerlag, Berlin, p 289-297

Teplitski M, Chen H, Rajamani S, Gao M and 5 others (2004) Chlamydomonas reinhardtii secretes compounds that mimic bacterial signals and interfere with quorum sensing regulation in bacteria. Plant Physiol 134:137-146

Thompson FL, Thompson CC, Naser S, Hoste B, Vandemeulebroecke K, Munn C, Bourne D, Swings J (2005) Photobacterium rosenbergii $\mathrm{sp}$ nov. and Enterovibrio coralii sp. nov., vibrios associated with coral bleaching. Int J Syst Evol Micr 55:913-917

Weidner S, Arnold W, Pühler A (1996) Diversity of uncultured microorganisms associated with the seagrass Halophila stipulacea estimated by restriction fragment length polymorphism analysis of PCR-amplified 16S rRNA genes. Appl Environ Microb 62:766-771

Weil E, Smith GW, Gil-Agudelo DL (2006) Status and progress in coral reef disease research. Dis Aquat Org 69:1-7

Wild C, Huettel M, Klueter A, Kremb SG, Rasheed MYM, Jørgensen B (2004) Coral mucus functions as an energy carrier and particle trap in the reef ecosystem. Nature 428: 66-70

Yasumoto T, Yasumura M, Yotsu M, Michishita T, Endo A, Kotaki T (1986) Bacterial production of tetrodotoxin and anhydrotetrodotoxin Agr Biol Chem 50:793-795

Submitted: May 7, 2006; Accepted: July 18, 2006

Proofs received from author(s): September 5, 2006 